\title{
АНТРОПОЛОГІЧНО-РЕЛІГІЙНІ ВИМІРИ СТРАХУ
}

У статті представлено систематизацію матеріалів філософсько-антропологічного та релігійного дискурсів щодо проблеми страху, особливостей ї̈ інтерпретації. Здійснено пошук релігійних коренів страху та їх актуальність у сучасному глобалізованому світі. Обтрунтовано тезу про те, що не зважаючи на те, щу людство змогло усвідомити і навчилося жити із природними страхами (боязню атмосферних явищ, природних катаклізмів, вулканів, землетрусів), воно досі залитається безпорадним та безсилим у ситуаціях зустрічі із соиіальними та екзистенціальними страхами (самотності, несподіваної небезпеки, невизначеності, випробувань, відповідальності, непередбачуваного майбутнього тощо).

Ключові слова: страх, природні страхи, соціальні та екзистенщіальні страхи, релігійні корені страху, антропологічні виміри страху, модуси сучасного життя.

Постановка проблеми. Сучасному інформаційному суспільству властива свобода у їі різноманітних проявах. Проте незважаючи на те, що свобода принесла незалежність індивіду, вона водночас ізолювала його, переповнила тривогами, безсиллям, невпевненістю, розгубленістю та страхами. Тривоги й страхи за власне майбутнє і майбутнє дітей породжені беззахисністю і непередбачуваністю глобалізованого суспільства. Актуальність дослідження обумовлена тим, що проблема страху займала важливе місце в усі періоди розвитку людства, але особливої актуальності вона набуває в умовах трансформації суспільства. У часи, коли паралельно позитивним процесам відбувається знищення загальнолюдських моральних норм і цінностей, а найголовнішими стають матеріальні блага і статки.

Щодня людина постає перед вибором: позбавитись від свободи чи залишити безмежну свободу, залишитись самодостатньою, незалежною, розумною й об’єктивною. Саме втечею від свободи ми можемо пояснити властиве людині прагнення до володіння речами, а їх накопичення - як модус заперечення страху залишитися наодинці із собою і власною свободою. Саме страх смерті, на думку стародавніх мислителів Демокріта, Епікура, Лукреція Кара зумовлював у первісних людей послаблення раціонального відображення дійсності і сприяв виникненню фантастичних уявлень, що слугували джерелом релігійних вірувань. Як зазначає сучасний дослідник М. Мовчан : "Думки про страх як причину виникнення релігійних вірувань беруть свій початок від античних теорій походження релігії" [1: 90]. Відмінністю є лише те, що у сучасному суспільстві, страх не лише тримає людину у мобілізаційній готовності, а й повертає іiі до духовного. А відповідно виникає потреба обгрунтування не лише філософсько-антропологічних, а й релігійних засад страху.

Аналіз основних досліджень і публікацій із зазначеної проблеми. Актуальність проблеми страху засвідчує й існуюча кількість напрацювань представників не лише філософії та психології (М. Бердяєв, Є. Боровой, І. Бичко, Л. Газнюк, Л. Горохова, П. Гуревич, А. Замалєєв, А. Корольков, А. Камю, С. К'єркегор, В. Мельник, М. Мовчан, Р. Мей, Б. Паскаль, О. Ранк, Ф. Ріман, М. Савіна, Ж.-П. Сартр, П. Тілліх, О. Туренко, З. Фрейд, О. Фролова, Е. Фромм, М. Хайдеггер, Н. Хамітов, К. Хорні, Л. Шестов, Ю. Щербатих, І. Ялом, К. Ясперс), а й інших галузей не тільки наукового знання, а й богослов’я. Так православне богослов'я в межах христології, сотеріології та антропології спрямовує людину стати божественною і в співпраці з Богом досягти духовного й божественного розвитку. Духовно збагачена людина здатна до альтруїстичного подвигу на благо іншим, вона відмовляється від власної волі, свого особистого блага, вона віддає все, що має, вона віддає себе і відмовляється жити лише для себе. Вона розглядає інших як образи Божі. Таким чином, у концепції відкуплення визначальне місце займає подолання людиною страху смерті, яке зумовлює іiі трансформацію та відродження. Звернення ж до екзистенціалу страху в умовах екзистенційно-антропологічної кризи М. Мовчан пов'язує з формуванням такого образу світу, який породжується відчуженням від природних усталених цінностей і норм. У той же час, С. Гош і С. Чаттаржі зауважують на тому, що страшні спогади мають вирішальне значення для виживання. Однак надмірне узагальнення таких спогадів, що характеризуються нездатністю розрізняти небезпечні від безпечних стимулів, поширене в тривожних розладах. Сучасна дослідниця В. Мельник відзначає, що "мотиваційна діяльність людини керується страхом перед новим не вивченим простором та часом самотністю перед богом та трансцендентним. Почуття страху присутнє в кожній живій істоті, але в більшій мірі реальне для людини з тонкою душевною організацією" [2: 47]. Відтак, подвійна природа страху може не лише конституювати суспільство, а й нівелювати індивідуальні та суспільні засоби захисту. 
Окреслення невирішених питань, порушених у статті. Проте, не зважаючи на наявні напрацювання у світовій і вітчизняній філософській думці проблема релігійних коренів страху залишається малодослідженою. Представлена стаття є спробою пошуку й опрацювання не лише антропологічних, а й релігійних засад страху як важливого модусу життя сучасної людини в умовах глобалізації. Адже не зважаючи на досягнення науково-технічного і науково-технологічного прогресів ми повинні навчитися не лише жити поряд зі страхами, а й вміти усвідомлювати та контролювати їх, оскільки XXI століття актуалізує проблему страху, що потребує їі осмислення у міждисциплінарному зрізі.

Мета та завдання дослідження. Подібно до того, як безсилля первісних людей перед силами природи і невідомими раніше суспільними проблемами, у сучасному світі страх непередбачуваного і невідомого майбутнього актуалізує необхідність його дослідження не лише в антропологічному, а й релігійному дискурсах. Актуальність обраної теми зумовлена й тим, що люди часто роблять життєво важливий вибір зі страху. Людина в першу чергу боїться свободи. Види рабства як відмова від свободи: поневолення силам природи; рабство у соціуму; влада речей; рабство у самого себе. Як навчитися не боятися свободи? Розв'язанню окреслених питань і буде присвячено нашу статтю.

Виклад основного матеріалу. Страх свободи, як страх перед Ніщо, розкриває людське буття як унікальну сутність, здатну не лише ставити питання про свої основи, а й виходити за власні межі. Завдяки тривогам і страхам людина має можливість усвідомлювати безкінечні сумніви і заперечення себе. Підтвердженням зазначеного є думка Ж.- П. Сартра про те, що людина визнає свою свободу в тривозі, оскільки страх-тривога $є$ спосіб буття свободи: "Тільки в тривозі я осягаю себе як істоту тотально вільну. В активності цього буття світ лише й знаходить смисл" [3]. Отже, страх перед свободою - це страх перед Ніщо. Проте виникає певний парадокс, якщо Ніщо виявляється глибиною первісної свободи свідомості, що є необхідною умовою будь-якого питання або творчості, то свобода $\epsilon$ джерелом сутнісної тривоги, а отже свідомість свободи постає у формі тривоги. Страх бентежить свідомість, і тому вона прагне до предметної роздробленості, у страху свідомість переживає свободу як досвід Ніщо. Вічне вислизання від себе і повернення $є$ існуванням на межі власного пізнання, де страх проявляє себе. Ми існуємо, як страх і неспокій, і лише таким чином свідомість здатна існувати, як свідомість, що пізнає і творить сама себе як нову реальність. Ці нескінченні відчуття страху й визначають істину людського буття. Людина існує то у вічному прагненні до свободи, відкидаючи все, що одночасно обмежувало б ії й забезпечувало безпеку та затишок, то у втечі від неї саме тому, що свобода пробудила в ній безсилля і страх. Саме страх, неуцтво та обман французькі мислителі доби Просвітництва визначали джерелами виникнення релігійних поглядів. Як слушно зазначає О. Фролова, "на думку П. Гольбаха, страх є психологічним рівнем проблеми існування релігії: невідомі явища природи породжують у людей почуття занепокоєння, нестійкості, небезпеки і тривоги" [4: 58]. Подібно до первісного, інформаційне суспільство знову опинилося у полоні страху, який не тільки збільшує інтенсивність прояву, а й набуває глобального характеру.

У сучасному суспільстві страх не лише стає невід’ємною складовою, а й визначає стратегію поведінки індивіда. Сьогодні, знаходять підтвердження висловлювання С. К'єркегора про те, що страх є симпатичною антипатією й антипатичною симпатією, оскільки будучи "можливістю свободи", страх має "абсолютну виховну цінність" . Він "поглинає все конечне" і навчає індивіда віддавати себе Провидінню, і тоді віра робить його здатним побачити все у новому світлі, а значить, "одержати все знову як ніхто інший у дійсності" [5: 205]. 3 одного боку, людина боїться можливості, яка закладена в страху, але 3 другого,- вона якраз і прагне реалізувати цю можливість, оскільки вона $є$ забороненою. У цьому і розкривається двозначність страху: через страх людина стає винною, і водночас вона є невинною. У той же час, як зазначає С. К'єркегор, "людина, яка заперечує себе і жертвує собою заради боргу, віддає кінцеве, щоб схопити нескінченне" [5: 60]. Саме відчуваючи страх людина може осягнути справжнє буття, страх дозволяє людини виявити справжнє існування, відчути себе людиною, а не твариною чи іншою істотою. Відчуття повної порожнечі між власним життям і повсякденними цінностями в полоні страху дозволяє людині екзистенційно усвідомити небуття. Саме такий страх, на думку С. Борового, "є вираженням недостатності буття, як людини, так і світу" [6: 26]. Беззаперечною в наш час залишається також думка С. К’єркегора про те, що в кожному наступному роді треба більше чуттєвості, ніж в попередньому, тому й страх в майбутньому індивіді більш рефлексивний, ніж у попередньому. Це означає, що у кожному майбутньому індивіді збільшується певна схильність до гріха. Дійсно, навіть сучасна людина боїться можливості, яка закладена в страху, хоча 3 другого боку,вона якраз і прагне реалізувати цю заборонену можливість. Мислитель також пропонує психологічне пояснення страху, що присутній у кожній людині, з точки зору християнства. Саме первородний гріх, за визначенням С. К'єркегора, лежить в основі страху, який є станом, що передує будь-якому гріху.

Зважаючи на актуальність зазначеного питання пропонуємо більш детально зупинитися на інтерпретації окресленої проблеми у різних релігіях та православній теології. Саме страх був однією із важливих причин виникнення релігії. У той час, коли первісна людина не мала достатньо знань і навичок щоб відрізнити реальні небезпеки від нереальних "щоб якось умилостивити ворожий до себе світ, знайти 
з ним спільну мову, люди почали "олюднювати" природу, вважати іiі живою ..., з’являється можливість "домовитися" з ними і за допомогою дарів чи молитов відвести від себе біду" . Американський дослідник, засновник саєнтології та діанетики Л. Ронн Хаббард зауважує, що в первісному суспільстві "демони і дияволи- це хитре творіння тих, хто у прагненні підкорити собі своїх співплемінників спочатку придумував для них джерело страху, а потім виступав у ролі посередників..." [7]. На думку дослідника, чим більше страху "наганяли" жерці на суспільство, тим більшим авторитетом вони користувались. Подібно до первісного суспільства представники сучасної влади достатньо вдало використовують маніпуляцію страхами для того, щоб одержати потрібний результат. Позаяк маніпулювати наляканими людьми значно легше, аніж тими, які знають що робити і як. Перехід від політеїзму (багатобожжя) до монотеїзму (єдинобожжя) дослідники пояснюють тим, що "домовлятись" із великою кількістю надприродних істот було складно, тому з розвитком релігії кількість богів зменшується. Відповідно, релігійні концепції тлумачать страх як не що інше, як страх перед богом, божествами, духами (злими і добрими), божественним покаранням, несамовитими муками тощо.

Відповідне місце страх займає в буддизмі, у розумінні якого людина зможе успішно подолати страх тоді, коли позбавиться не лише від його причин, а й умов та наслідків. Це означає, що вона повинна заспокоїтись (позбутися зайвих емоцій), осилити відповідні дії і тенденції (карму), позбавитися повсякденних моделей поведінки тощо. Використання людиною абстрактного мислення допомагає збагнути (усвідомити) страх, а коли вона розуміє його (страх), то перетворює цей стан із негативного на позитивний. Оскільки у свідомості людини страх виникає як результат невідомості, незнання i нерозуміння, то відповідно його усвідомлення дозволяє їй зрозуміти саму себе. Відповідно, чим швидше вона це зробить, тим менше шансів у страху акумулюватися і охопити все єство людини.

Дещо іншим є розуміння і тлумачення страху у монотеїстичних релігіях. Так, християнство протиставляє страх свободі, а точніше воно акцентує свою увагу на свободі від страху (це не торкається "страху Божого", який згідно 3 християнськими канонами є однією з головних доброчесностей адептів цієї релігії). Проте, у християнському богослов’ї стан Божественної плоті не ідентифікується зі станом людської природи, що призводить до появи суперечливих трактувань. Цей аспект розкривається у вченні про безгріховність Христа, де зазначається, що гріх не приналежний людській природі, а $є$ лише ії викривленням. Людина вільна від потягу до гріховності, від внутрішньої спокуси та чуттєвої залежності. Тому твердження Г. Флоровського, що людська воля Христа була первинною й безгріховною, суперечать євангельським свідоцтвам. У даному контексті Іван Дамаський визначає дві Його волі: "Коли Божественна воля ставала меншою за ступенем впливу, тоді людська воля проявляла свої властивості. Так, заперечуючи смерть Господь став молитися про ії відвернення, перебуваючи в страху" [8: 110]. Ці слова засвідчують, що плоть Ісуса Христа, тотожна людській за сутністю, у той же час відмінна в екзистенціальному значенні [9: 310]. У даному аспекті ця відмінність на рівні існування визначається не станом людської природи Христа, а іiї приналежністю до Божественної іпостасі, чим пояснюється відсутність гріховного бажання Його людської волі. Саме в якості обгрунтування такого положення вказується на автономну екзистенцію єства людини.

Проте, зважаючи на те що спасіння залежало від розвитку антропологічних уявлень. У контексті їх становлення Г. Флоровський виокремлює дві антропологічні доктрини: "антропологічний мінімалізм" та "антропологічний максималізм" . Основоположником першого типу антропології був Аполлінарій Лаодикійський, вважаючи, що людина наділена грішним розумом, який не може бути врятованим. Саме антропологічна доктрина Аполлінарія визначила христологічну концепцію Христа, який ввібрав лише зовнішні риси людської природи. Констатуючи це, Аполлінарій зводить антропологізм у сотеріологічну площину. Таким чином, на думку Я. Москалика, антропологічний мінімалізм, який за словами Г.Флоровського "виражав песимістичну оцінку людської природи", призводив до виокремлення Божественної природи в Христі. А в кінцевому підсумку - "заперечення людського розуму, як вираження страху перед мисленням" [10: 65]. Людина, яка створена за образом, покликана досягти подоби Бога, тому іiі ставлення - це безпосередній духовний досвід. Православне богослов'я формує теоцентричний погляд на людину із спільним буттям та творчістю. Людина повинна подолати тварне обмеження, брати участь у божественному житті. Тому христологія, за твердженням М. Мельника [11], формує образ досконалої людини, яка перестає бути природною істотою і підноситься до реальності свого існування. Христос поновлює втрачену єдність Бога та людини. Людська і Божественна природи Христа визначають подвійну сутність людини, це дозволяє їй пізнати Бога та спілкуватися з Ним. Зміни, які людина переживає в своєму житті через створення власного світу, як творча істота, відбуваються під впливом христологічного вчення. Лише покірлива людина вважається повноцінним християнином, та яка є смиренною перед Богом. У той же час, покірливість потрібно розглядати не як м'якотілу байдужість чи приниження людини, а як вищу форму безстрашності.

Таким чином, досконалою є справжня, відкрита людина, існування якої спрямоване на онтологічну єдність із трансцендентним, обумовлюючи христологічний зв'язок в іпостасне з'єднання. Визначивши основні етапи становлення досконалої людини, буде виправданим, 3 методологічної точки зору, 
концептуально визначити христологічні ідеї, які $\epsilon$ основоположними в антропології православного вчення. Святоотцівська традиція визначала досконалість людської природи Христа в абсолютній повноті безгріховного людського буття. Зокрема, Ігнатій Антіохійській, зазначав, що: "Він (Христос) зробився людиною досконалою" [12:74]. Для більшості святих отців досконалість означала природну повноту і етичну довершеність Ісуса.

Подібним до християнства є відношення до страху й у прихильників ісламу, на думку яких страх розгнівати Аллаха, породжує боязнь розплати і муки пекла. У Корані зазначено, що потрібно не лише прославляти, а й боятися Аллаха: "Ті, які увірували! Бійтесь Аллаха, і нехай душа подивиться, що вона приготувала на завтрашній день. Бійтесь Аллаха, адже Аллах відає про те, що ви робите. Не уподібнюйтесь тим, хто забув Аллаха" [13, 59: 18-19]. Подібним до християнського диявола є ворожий Аллаху і людям злий дух Шайтан - нечиста сила, яка постійно вселяє страх, є джерелом бід, нещасть і ворогом спасіння людства [13, 58: 18-20]. Дійсно, лише віруюча людина сподівається на Христа або Аллаха, що дозволяє їй не втрачати контроль над собою, зберігати ясність розуму та спокій, аналізувати власну поведінку й успішно досягати бажаного результату. I в християнському і мусульманському віровченнях присутній різновид страху, який є вищою доброчесністю, це - благородний страх, страх Божий. В ісламі цей страх пов'язують 3 абсолютною любов'ю до Аллаха і він обов'язково повинен бути у кожного.

У той же час, якщо Новий Заповіт більш просякнутий ідеєю любові, то у Старому Заповіті домінує міркування щодо страху перед Господом. Присутність якого засвідчено у Святому Письмі : "Служіть Господу зі страхом і радійте з тремтінням", вказано в другому псалмі Давида (Псалом 2: 11). Християнство акцентує увагу на тому, що зі страхами безпосередньо пов'язані й такі смертні гріхи як: гординя, марнославство, користолюбство (жадібність), гнів, обжерливість (черевоугодництво), зневіра, хтивість (блуд), заздрість, лінивство, нестриманість, нечистота. Гріх - це залежність і страх, стрес і депресія. Християнське віровчення також засуджує насилля і гнів, які можуть бути безсумнівним результатом дії страху на людей. Насилля є спробою маніпулювати кимось, підкоряти його, отримувати контроль над ним за допомогою страху. Слушною у цьому випадку є думка Ю. Щербатих про те, що чим більш незрозумілим $\epsilon$ щось для людини, тим значно більший страх воно може викликати (яскравим прикладом є обряди перших християн, які були прості і зрозумілі та проводились рідною мовою, але вже в Середні віки вся церковна служба здійснювалася латинською мовою, чужою для більшості мешканців Європи) [14: 404-405]. Дещо іншою є психологічна форма маніпуляції, що може використовуватися без застосування прямого насилля. Такий вплив має гнів як сильне нервове збудження, що проявляється у злості людини як до певного об’єкту, так і до цілого світу.

Обгрунтування отриманих наукових результатів. Здійснене дослідження дозволило з'ясувати, що не зважаючи на те, що в процесі еволюції людини 3 появою свідомості тваринний страх змінюється соціальним, небезпека від дій індивіда сприймається як колективна, а страх сприяє виробленню засобів, направлених проти зоологічного індивідуалізму. Вимога утриматися від небезпечних для суспільства дій має стати основою нормативного регулювання життя сучасного суспільства. Відповідно до християнського віровчення, тільки покірлива й смиренна перед Богом людина є повноцінним християнином. Проте, покірливість потрібно розглядати не як м'якотілу байдужість чи приниження людини, а як одну із форм безстрашності. У сучасному суспільстві чинниками страхів є пристрасті і прихильності, бажання мати щось або небажання втратити певні цінності (здоров'я, життя, майно тощо). Боротьба з пристрастями - це, перш за все, боротьба з залежностями, це шлях до звільнення. Ще Апостол Павло зазначав : "мені все дозволено, але не ніщо не повинно володіти мною". Переглянувши список смертних гріхів, можна побачити, що всі вони про страх, залежність і спроби володіти або управляти. Відповідно обжерливість та блуд теж $\epsilon$ прикладами залежності від тілесних бажань, а любов до грошей пов'язана зі спрагою володіння і влади. Марнославство породжене залежністю від думок людей або жагою визнання. Гнів, як уже було зазначено $є$ результатом страху і відчайдушної спраги повернути контроль. Розуміючи, що залежність, несвобода i страх - це "коріння зла" в будь-якому гріху, можна уточнювати і розширювати цей список.

Висновки та перспективи подальших досліджень проблеми. Слід погодитися 3 думкою В. Мельник, яка зазначає що "Важливою в соціально-теософських трактуваннях страху є фіксація того, що страх не пригнічує, а навпаки, активізує діяльність людини. Зокрема, робиться акцент на те, що страх об'єктивується в культурі і піддається механізму мінімізації" [2: 47]. Слід зазначити, що слушною у наш час є думка М. Мовчана про те, що, люди не зважаючи ні на що "не повинні боятись втратити ні фізичні (майно, здоров'я, життя), ані символічні (репутація, повага, статус) цінності. Вони мусять знати, що кожна людина тимчасова у цьому світі, їй нічого не належить. На все є воля Божа. Головне - це надія на Бога, адже всі значні цінності християнина перебувають поза межами цього життя. Людині потрібно змиритись і діяти згідно з волею Божою, не проявляти при цьому насилля і гніву, а бути безстрашною (тобто покірливою)" [1:92]. Сучасний світ спонукає людину вчитися жити поряд зі страхами. Страху не можна уникнути, він виникає у кожній спробі ствердження себе як нового "Я". Страх таїться у кожному передбаченні майбутнього, водночас, він примушує людину "існувати". 
Можемо сказати, що страх водночас $\epsilon$ i небезпечним i благодатним здобутком людини, фундаментальною особливістю іiі буття. Більше того, у сучасному суспільстві страх стає одним із способів самопізнання людини, поряд зі смертю, свободою, любов’ю, оскільки чи кожен у глобалізованому світі розуміє себе як смертного, вільного, люблячого і, нарешті, страждаючого. Людина наділена свободою волі, тому все залежить від кінцевого результату - хтось обирає спасіння, а хтось іде іншим шляхом... Ми постійно перебуваємо у полоні тривог і страхів, проте розвинена уява, дозволяє адаптуватися до складних умов життя ... Яскравим прикладом є страхи відповідальності чи страхи перед випробуванням, у яких опиняються наші військові перебуваючи в зоні АТО. Події та екстремальні умови викликають постійне відчуття страху смерті, який не тільки допомагає зберігати власне життя, а й породжує страждання особливо у ситуаціях вибору між власним життям і життям супротивника. У той же час, на мирній території люди перебувають у полоні таких страхів як: страх самотності, тривога, страх несподіваної небезпеки, страх невизначеності, страх непередбачуваного майбутнього, панічний страх тощо. Зазначене не лише підтверджує актуальність обраної теми, а й необхідність ії всебічного міждисциплінарного аналізу і окреслює перспективи майбутніх досліджень присвячених зазначеним питанням

\section{СПИСОК ВИКОРИСТАНИХ ДЖЕРЕЛ ТА ЛІТЕРАТУРИ}

1. Мовчан М. Страх і релігія у філософсько-антропологічному дискурсі / М. М. Мовчан // Актуальні проблеми філософії та соціології. - 2017. - № 15. - С. 90-93.

2. Melnyk V. V. Fear Phenomenon in Existential Philosophy / V. V. Melnyk // Anthropological Measurements of Philosophical Research. - Issue 11, 2017. - C. 41-48. - DOI : 10.15802/ampr.v0i11.105476.

3. Jean-Paul Sartre L'être ET le néant : Essay d'ontologie phénoménologique [Електронний ресурс] / Sartre JeanPaul. - P.: Gallimard, 1943. - M. : "Республика" , 2000. - Режим доступу : http://psylib.org.ua/books/sartr03/txt00.htm.

4. Фролова О. С. Феномен страха в культуре : дис. ... канд. филос. наук : спец. 24.00 .01 / О. С. Фролова. Ростов-на-Дону, 2006. - 133 с.

5. Кьеркегор С. Страх и трепет. Понятие страха. Болезнь и смерть./ С. Кьеркегор ; [пер. с дат.]. - М. : Республика, 1993. - 383 с.

6. Боровой Е. М. Страх и социальное бытие человека : дис. ... канд. филос. наук: спец. 09.00.11/ Е. М. Боровой. - Новосибирск, 2006. - 181 с.

7. Хаббард Р. Страх [Електронний ресурс]/ Л. Ронн Хаббард. - Режим доступу : http://librebook.me/strah 3/vol1/1.

8. Дамаскин И. Точное изложение православной веры. Кн. II. Вопросоответы к Фалассию/ Преподобный Иоанн Дамаскин : [Пер. А. А. Бронзова и Д. Е. Афиногенова]. - М., 1992. - 446 с.

9. Мейендорф И. Иисус Христос в восточном православном богословии / прот. Иоанн Мейендорф // Пер. с англ. свящ. Олега Давыденкова, при уч. Л. А. Успенской, примеч. А. И. Сидорова. - М. : ПСТБИ, 2000. $318 \mathrm{c}$.

10. Москалик Я. Нарис христологічної доктрини / Я. Москалик. - Л : Вид-во ЛБА : Свічадо, 1998. - 88 с.

11. Melnyk M. Prawosławna antropologia soteriologiczna/ Marek Melnyk / W kręgu sacrum i pograniczan [red. E. Matuszczyk, M. Krzywosz]. - Białystok, 2004. - S. 157-178.

12. Булгаков С. Агнец Божий : О богочеловечестве / прот. Сергий Булгаков. - T. 1. - Париж: YMCA-Press, 1933. $-468 \mathrm{c}$.

13. Коран онлайн [Електронний ресурс]. - Режим доступу : http://quran-online.ru/58/saadi.

14. Щербатых Ю. В. Психология страха : популярная энциклопедия / Ю. В. Щербатых. - М. : Эксмо, 2007. $512 \mathrm{c}$.

\section{REFERENCES (TRANSLATED \& TRANSLITERATED)}

1. Movchan M. Strakh i relihiia u filosofs'ko-antropolohichnomu dyskursi [Fear and Religion in Philosophical and Anthropological Discourse] / M. M. Movchan // Aktual'ni problemy filosofii ta sotsiolohii [Actual Problems of Philosophy and Sociology]. - 2017. - № 15. - S. 90-93.

2. Melnyk V. V. Fear Phenomenon in Existential Philosophy/ V. V. Melnyk// Anthropological Measurements of Philosophical Research. - Issue 11, 2017. - C. 41-48. - DOI : 10.15802/ampr.v0i11.105476.

3. Jean-Paul Sartre L'être ET le néant : Essay d'ontologie phénoménologique [Elektronnyi resurs] / Sartre Jean-Paul. P. : Gallimard, 1943. - M. : "Respublika", 2000. - Rezhym dostupu : http://psylib.org.ua/books/sartr03/txt00.htm.

4. Frolova O. S. Fenomen straha v kul'ture [The Phenomenon of Fear in Culture] : dis. ... kand. filos. nauk: spets. 24.00 .01 / O. S. Frolova. - Rostov-na-Donu, 2006. - $133 \mathrm{~s}$.

5. Kerkegor S. Strakh i trepet. Ponyatie straha. Bolezn' i smert' [Fear and Trembling. The Concept of Fear. Illness and Death] / S. Kerkegor ; [per. s dat.]. - M. : Respublika, 1993. - 383 s.

6. Borovoy E. M. Strakh i sotsial'noe byitie cheloveka [Fear and Social Being of a Person] : dis. ... kand. filos. nauk: spets. 09.00.11 / E. M. Borovoy. - Novosibirsk, 2006. - $181 \mathrm{~s}$.

7. Habbard R. Strakh [Fear] [Elektronnyi resurs]/ L. Ronn Habbard. - Rezhym dostupu : http://librebook.me/strah_3/vol1/1.

8. Damaskin I. Tochnoe izlozhenie pravoslavnoi very. Kn. II. Voprosootvetyi k Falassiyu [Exact Statement of the Orthodox Faith. Book II. Question Answer to the Falassia] / Prepodobnyi Ioann Damaskin : [Per. A. A. Bronzova i D. E. Afinogenova]. - M., 1992. - $446 \mathrm{~s}$. 
9. Meyendorf I. Iisus Hristos v vostochnom pravoslavnom bogoslovii [Jesus Christ in Eastern Orthodox Theology]/ prot. Ioann Meyendorf// Per. s angl. sviasch. Olega Davyidenkova, pri uch. L. A. Uspenskoy, primech. A. I. Sidorova. - M. : PSTBI, 2000. - 318 s.

10. Moskalyk Ya. Narys khrystolohichnoi doktryny [Essay on Christological Doctrine] / Ya. Moskalyk. - L. : Vyd-vo LBA : Svichado, 1998. - $88 \mathrm{~s}$.

11. Melnyk M. Prawosławna antropologia soteriologiczna [Essay on Christological Doctrine] / Marek Melnyk / W kręgu sacrum i pogranicza [red. E. Matuszczyk, M. Krzywosz]. - Białystok, 2004. - S. 157-178.

12. Bulgakov S. Agnets Bozhii [Lamb of God : About God-Manhood]: O bogochelovechestve/ prot. Sergii Bulgakov. - T. 1. - Parizh : YMCA-Press, 1933. - $468 \mathrm{~s}$.

13. Koran onlain [Quran Online] [Elektronniy resurs]. - Rezhym dostupu : http://quran-online.ru/58/saadi.

14. Scherbatykh Yu. V. Psihologiia straha [Psychology of Fear] : [populiarnaia entsiklopediia] / Yu. V. Scherbatykh.M. : Eksmo, 2007. - $512 \mathrm{~s}$.

\section{Горохова Л. В. Антропологическо-религиозные измерения страха.}

В статье представлено систематизацию материалов философско-антропологического и религиозного дискурса по проблеме страха, особенностей его интерпретации. Осуществлен поиск религиозных корней страха и их актуальность в современном глобализированном мире. Обоснованно тезис о том, что, несмотря на то, что человечество смогло осознать и научилось жить с природными страхами (боязнью атмосферных явлений, природных катаклизмов, вулканов, землетрясений), оно до сих пор остается беспомощным и бессильным в ситуациях встречи с социальными и экзистенциальными страхами (одиночества, неожиданной опасности, неопределенности, испытаний, ответственности, непредсказуемого будущего и т.д.).

Ключевые слова: страх; природные страхи, социальные и экзистенциальные страхи, религиозные корни страха, антропологические измерения страха, модусы современной жсизни.

\section{Horokhova L. V. Anthropological and Religious Measurements of Fear.}

The purpose of the article is to study the actual, but not fully understood, problems of anthropological and religious concepts of fear. The theoretical basis for intelligence served as the works of representatives of the existential and psychoanalytic philosophy of M. Heidegger, A. Camus, S. Kierkegaard, F. Riemann, J.-P. Sartre, P. Tillich, Z. Freud and the work of modern scholars E. Borovy, L. Ghaznyuk, I. Ilyin, A. Kurpatov, M. Movchan, O. Frolova, Yu. Shcherbatykh, as well as sacred books of world and national religions. The scientific novelty of the publication is to systematize the materials of philosophical-anthropological and religious discourses on the problem offear, the peculiarities of its interpretation, as well as in an attempt to substantiate the religious roots

of fear and their interrelation with the modern conditions of society's life. Modern man, despite the latest achievements and opportunities, remains in captivity of fears. Awareness of temporality motivates a person to act, despite fears and limitations. At the same time, a believer is in captivity of at least two varieties of fear: the carnal and the fear of God. Given the circumstances and events in the life of contemporary Ukrainian society, the problem outlined requires the study of its new aspects, namely: actualization of new varieties of fear at the present stage of human development, as well as identifying their possible parallels with the past. An important issue is the search for the religious roots of fear, as well as their relevance in today's globalized world. Despite the fact that humanity was able to realize and learned to live with natural fears (fear of atmospheric phenomena, natural disasters, volcanoes, earthquakes), it still remains helpless and powerless in situations of encounter with social and existential fears. A striking example is the fears of responsibility or fears before the trial, which our military finds in the ATO zone. Events and extreme conditions cause a constant sense of fear of death, which not only helps to preserve their own lives, but also causes suffering, especially in situations of choice between their own lives and the life of the enemy. At the same time, in the peaceful territory people are in captivity of such fears as: fear of loneliness, anxiety, fear of unexpected danger, fear of uncertainty, fear of unpredictable future, panic fear and so on. The above not only confirms the relevance of the chosen topic, but also the necessity of its comprehensive multidisciplinary analysis.

Key words: fear, natural fears, social and existential fears, the religious roots of fear, anthropological dimensions offear, modes of modern life. 